\title{
Inside here: daydreaming space and the digital monument
}

\author{
Karen Bosy, Royal College of Art \\ karen.bosy@ network.rca.ac.uk
}

\begin{abstract}
This paper starts by considering the theories of Henri Lefebvre and Rosalind Krauss to outline an understanding of monumentality, drawing on the theories of the well-respected geographer and theorist Doreen Massey, which support the importance of understanding the relationality of site. Following on from this, the role of the monument, and the monument's connection to imagination and daydreaming, in art practice is explored. Strategies including Modernist reductionism and unmonumental/anti-monumental art practice are exemplified by artists' works explicitly concerned with the 'monument' and the 'monumental', and the questions these works raise are discussed with respect to my own documentarist art practice as represented by artworks included in the Intentions exhibition in 2017: the zine what is public space?, 2017, the moving image artwork, vault, 2017, and collaborative sound artwork Script, 2017.
\end{abstract}

Key-words: daydreaming, imagination, art practice, monument, relational space 
"Monuments project onto the land a conception of the world... proclaim[ing] duty, power, knowledge, joy, hope", writes Henri Lefebvre in The Urban Revolution, 1970. (p.22) For Lefebvre, monuments symbolically communicate cultural information that is transmitted, through the passage of time, into future contexts. In this way monuments are continuously recontextualised in the "stories-so-far" that constitute relational space, as Doreen Massey explains "space/time" in For Space (2005). In agreement with this, Rosalind Krauss in Sculpture in the Expanded Field, published in October Magazine (1979), theorises that "the logic of sculpture and the logic of the monument" are "inseparable" (p.33), illustrating this with the example of the statue of Marcus Aurelius in the Campidoglio, Rome, which represents "by its symbolical presence the relationship between ancient, Imperial Rome and the seat of government of modern, Renaissance Rome". It forms a "marker at a particular place for a specific meaning/event" (p.33).

For Krauss, a monument "sits in a particular place and speaks in a symbolical tongue about the meaning or use of that place", communicating regarding the particular place, its use or a specific meaning/event (p.33). This logic gradually faded during the late 19th century as the Modernist monument became an abstracted "pure marker or base, functionally placeless and largely self-referential" (Krauss, 1979, p.33-34). Ways in which similarly reductionist strategies have been used in relation to symbolic communication are explored by Boris Groys in The Weak Universalism republished in 2010 in the e-flux journal Going Public; for Groys, the artists of the avant-garde perceived as a destructive force the new technologies which were leading to continual change. They tried to resist this by "reducing cultural signs" (Groys, p. 109) in their images so they would be understood in new and unforeseen contexts and in this way transcend change and therefore time. Groys labels these artworks "weak" as they do not contain complicated and therefore "strong" signs (p.109 -110).

Practitioners taking positions on Modernist and previous monumental strategies include, for example, those of architect Bernard Tschumi, and artists Rachel Whiteread, Martha Rosler and Christo and Jeanne Claude. Tschumi, based in Paris and New York, published photographs of decayed modernist buildings presented as 'Advertisements For Architecture' in architectural magazines in the 1970's, underlining his polemical ideas including the importance of time and context in architecture. In these photographs, the decay wrought by time betrays the context that Modernism denied. Whiteread, as a post-minimalist artist, reacts against elements of Modernist reductionism in the sculpture House, 1993, by emphasising the importance of context, and exploring surface and spatial volume (Mullins, Rachel Whiteread, 2017). Looking at Modernism a different way, artist and theorist Martha Rosler contrasts Christo's and Jeanne Claude's public artwork The Gates with Richard Serra's modernist Tilted Arc (1981), (Culture Class, p.145) which was removed in 1989 from its site-specific location in Manhattan. The Gates, a site-specific artwork installed in New York's central park for two weeks in February 2005, allows more physical interaction as people walk through a "frame" onto a stage (Rosler, p.145). Rosler suggests the move to tactility exemplified by the contrast between these two artworks may be a turn to a "service/experience model" of public sculpture (p.145). However, when Tschumi, along with partner Colin Fournier, previously to The Gates, designed the Parc de la Villette (built 1984 - 1987), Paris, as a tactile space encouraging interaction and activity, he was perhaps taking a position in consideration of the new developments at the time in 
networked, public and interactive space. Viewed another way, perhaps The Gates, in allowing private individuals to "come into view" within a public space, parallels networked digital social media spaces, and interrogates the monument's role by exemplifying a model of public sculpture that provides experience.

Similarly, by isolating and recontextualising aspects of the monument, other art practices can interrogate the monument's role and the monument as a trope. The 2011 exhibition Unmonumental (at the new New Museum in New York, curated by Gioni Massimiliano, Richard Flood and Laura Hoptman), included artworks that can be described by two "related ideas: assemblage and unmonumentality", with "the former a strategy to achieve the latter" according to Laura Hoptman (Going to Pieces in the 21st Century, p.128). These artworks interrogate impermanence and contingency as well as pointing to concerns about new public and private digital spaces and ways in which symbolic communication can operate within these (p.138). For Hoptman, the adjective 'monumental' "connotes massiveness, timelessness and public significance", (p.138) qualities which the sculpture included in Unmonumental, as Hoptman explains, intentionally lacked and this was achieved through using assemblage as a strategy. Rachel Whiteread used a different strategy in her 2001 project, Monument, for Trafalgar Square's fourth plinth, eight years after the successful completion of House. With Monument, Whiteread aimed to create a "pause or quiet moment" (Mullins, Rachel Whiteread, 2017, p.97) in the busy circulation of Trafalgar Square, and in order to achieve this, Whiteread replicated the existing plinth (itself a listed monument), in clear resin, creating a ghostly reflection and an illusion of lightness. Although assemblage is not used as a strategy in this piece, Monument, as a 'light' and temporary installation interrogating the self-referential symbolic communication of the modernist plinth (Krauss, p.34), can be placed within the category of 'unmonumental' (as defined by Hoptman). Whiteread's post-minimalist strategies included recontextualising attributes of the monument (Mullins, Rachel Whiteread, p.97) to promote contemplation, resulting in an interrogation of the plinth and the role of 'marker' (Krauss, 1979, p.34). While Whiteread's Monument does not fulfil the logic of the monument, as explained by Krauss, as it is not a marker for a particular place or event but instead is a selfreferential and therefore 'nomadic' marker' (Krauss, 1979, p.34), Monument succeeds in achieving unmonumentality through interrogating the connotations of "massiveness, timelessness, and public significance" attributed to the monument (Hoptman, p.138).

Whiteread's "quiet moment" (Mullins, Rachel Whiteread, 2017, p.97) corresponds with the monument's connection to imagination and therefore daydreaming, an inherently human form of contemplation (Bachelard, 1957, p.6-7). This connection is clearly understood by Lefebvre's proposal that "Monuments project onto the land a conception of the world..." (1970, p.22) in connection with symbolic communication and the viewer's subjective reading. Exploring the monument in relation to symbolic and place-centred communication, Susan Hiller's installation Monument (1980-81), is an artwork that comments on the everyday, based on the artist's observations in a public park. The viewer can decide to participate in this installation, starting perhaps by looking at the photographs, choosing to sit on the bench to listen to the tape and then deciding "whether or not to engage in a private act of contemplation in public" (The Everyday, 2008, p.180). Hiller explains that her artworks are not about physical objects but are to do with the relationships of the space itself with everything included in it, objects, sounds, viewer and 
relationships between these within the space (The Everyday, 2008, p.180). In this way, Hiller's Monument uses the strategies of installation including "the privatisation of public space" (Groys, 2010, p.56) to recontextualise the monument's symbolic and place-centered communication concerning "the meaning or use of [a particular] place" (Krauss, 1979, p.33). Looking at this another way, Thomas Hirschhorn's Bataille Monument (2002), consists of a library located within a community for use by local people as well as by those visiting an international art event taking place nearby. This is an example of a large scale work where the viewer is asked "only to be a thoughtful and reflective visitor" and although Hirschhorn's relational spaces "are dependent on context" (Bishop, Out of Body, 2016), it is still possible to re-stage this artwork elsewhere in comparable circumstances (Bishop, 2016). Hiller's and Hirschhorn's installations are not marking a particular place or event but investigating relational space (Massey, 2005) and the promoting of imagination in relation to symbolic communication.

Doreen Massey's theories support the importance of understanding the relationality of site and, to this end, Massey theorises space as relational and as posing the "challenge of contemporaneous processual existence" (For Space, p.61) within which "places can be conceptualised as processes" (Space, Place and Gender, 2007, p.137). While investigating process and Spinoza's concept of imagination (quoting Gatens and Lloyd in For Space, 188), Massey explains that imagination (and therefore daydreaming) includes a physical (corporeal) component which is related to affect. In this case, although these installations are not 'marking' (Krauss, 1979, p.33) a particular place or event, it is possible they affectively 'mark' a relational space for the viewer through their connection to imagination. In this case, the successful mobilising of imagination in these artworks creating an affective 'marker', can be related to the ways in which a physical 'marker' operates within the 'logic of the monument' (Krauss, 1979, p.33). Taking the concept of the relational site further, Francis Alÿs and Rafael Ortega in their artwork One Minute of Silence (2003) ask people in a busy street and restaurant to request someone nearby for silence until one minute of silence was eventually achieved. By animating the act of 'marking' (Krauss, 1979, p.33) making it mobile and temporary, this proposed an 'alternative to the [static, permanent] official site of the monument.' (Rugg, 2010, p.65). Alÿs and Ortega's process-based artwork centers on a networked participatory and collaborative performance to create a relational experience (Massey) of the monument's connection to contemplation, and in this way decontextualises imagination and therefore also the affect, which is a part of imagination as Massey explains, associated with a 'marker' (Krauss, 1979, p.33).

These art practices mentioned use assemblage, sculpture, installation and performance to consider the modernist reductionist strategies outlined by Groys. For example, context is considered using post-minimalist strategies (Whiteread), installation (Hiller and Hirschhorn) and performance (Alÿs and Ortega). These practitioners are considering the monument using strategies that interrogate the marker in ways that fit within the definition Hoptman established for 'unmonumental'. Considering again Rachel Whiteread's House, through which Whiteread also questions Modernist understandings of monumentality through the use of post minimalist strategies (emphasising importance of context, surface and spatial volume), House, the demolition of which in 1993 was documented through newscasts and photographs, continues to be discussed in relation to its former site and its connotations are of monumental "massiveness, timelessness and public significance" rather than unmonumental "contingency" (Hoptman). It 
does not seem to fit with the unmonumental as it seems to take a more questioning attitude to the "logic of the monument" (Krauss, 1979, p.33). Although she "always intended [it] to be a temporary structure", Whiteread wanted House to "become a part of the fabric of the neighbourhood" (Mullins, Rachel Whiteread, p.56), indicating a relational dimension to the marking of the event as part of the intention of the piece. In making the marking relational, House subverts conceptions of the monument as an objective marker. This piece is usually considered in relation to the spot where it stood within the neighbourhood. It provided a physical marker (cast insides of house) at a specific site (Grove Road, London) with a particular symbolic communication. However, House is against the logic of the monument established by Krauss, because post-demolition the marker is no longer present at the site. In this case, some may consider it a failure - or flawed. If viewed as a process-based work, however, the process of its destruction is as much a part of the artwork as the making of it and its presence on site. As Massey theorises, "places can be conceptualised as processes" (Space, Place and Gender, 2007, p.137) and this is a way to explain the "stories-so-far" (For Space, 2005) that make up relational space. In this way, House as a process-based art form, continues to communicate symbolically about a particular place and fulfils this element of Krauss' 'logic of the monument', 'marking' its former site through the prompting of imagination. Because House questions monumentality as a whole, it can perhaps be considered to be different in this respect to the unmonumental works which consider elements of monumentality selectively. Laura Hoptman makes a distinction between 'unmonumental' and 'anti-monumental' sculpture (Going to Pieces in the 21 st Century, p.138). House fulfils 'the logic of the monument', yet questions monumentality's fundamentals. In this case, House can be considered in terms of the anti-monumental, considering the prefix 'anti', in a similar way to a literary 'anti-hero', to connote a questioning or alternative form; these are works that can be said to play on 'the logic of the monument' while still fulfilling its criteria according to Krauss.

'Unmonumental' artworks, as Hoptman explains, as well as interrogating impermanence and contingency point to concerns about new public and private digital spaces and ways in which symbolic communication can operate within these (p.138). In accordance with this and exemplifying a process-based collective artwork, the correspondence artists' networked 'event' is an example of the public artworks produced by artists of the 1970's and 1980's who challenged the "monumentality of public art" (Seth Price, Dispersion, 1998, zine, no page numbers) through an interrogation of the development of networked public space. According to Groys, and his system of weak and strong signs, the reductions made by the neo avant-garde artists (including the early correspondence artists) made the current networked social spaces possible. Groys suggests, "Without these artistic reductions effectuated by these artists, the emergence of the aesthetics of these social networks would be impossible and they could not be opened to a mass democratic public to the same degree" (p.117).

Although correspondence art fits within the 'unmonumental', it can exist as an antimonument, still in a way fulfilling the 'logic' of the monument (Krauss). In correspondence art, the action of exchange within a network that forms the existence of the postal system forms the 'specific meaning/event' (Krauss) in the work. Although this collective artwork subverts Krauss's concept of the monumental 'marker', as objectively fixed, the individual works of correspondence art 'mark' collectively the exchange which is facilitated by the postal system at 
the physical sites of the post office, such as the post boxes and sorting offices, and symbolising and communicating the values of these artists.

Academic and historian Mark Poster explores Derrida's book The Post Card (1980) in The Mode of Information (2007), explaining that "computer communications" can now "substitute for the postal system" as well as for the telephone and physical meetings (p.115). Both the postal system and computer communications have been used in exchange- or correspondencebased artworks, for example, computer communications are used by email art's DIWO participatory movement (Furtherfield, 2006). Following on from this, Seth Price suggested that the "collective experience is now based on simultaneous private experiences", such as the post, or (as a progression) the internet, and it may be, now, that a "popular album" might be a more successful example of public art than a "monument tucked away in an urban plaza" (Seth Price, 1998, zine no page numbers).

Within this progression, Donna Szoke's 2015 'anti-monument' artwork Invisible Histories, consisting of a film installation and a smartphone app, exemplifies artwork that uses smartphone technology to investigate the 'marker'. The digital networked element of this work involves the viewer performatively, as a graphic of a glowing green mouse runs across the screen indicating the viewer's location in relation to the site of an unmarked warehouse, the location of which is indicated only in relation to the viewer and otherwise unmarked. The relational nature of this marker allows the viewer to relate personally to the object marked, (engaging one's imagination). ${ }^{1}$ In this way this artwork fulfils the 'logic of the monument', aside from its lack of a conventional location marker, subverting conceptions of the monument as an objective 'marker' (Krauss) and making the marking affective and relational.

These three examples use process and dematerialised artworks to consider the monument's fundamentals. The 'marker' is reconsidered using affect (Whiteread), collectivity and participation (correspondence art) and performativity (Szoke). In this way these artworks create a questioning or alternative form which can be termed anti-monumental. In these, and in 'unmonumental' artworks, the ways in which imagination (and therefore daydreaming as a form of contemplation as explained by Bachelard) is mobilized are closely related to these artworks' interrogations of the monumental.

The theories of Lefebvre, Massey and Krauss form a frame for a developing definition of the monument, which combines Lefebvre's possible futures (transcendence), Massey's relational space and Krauss's 'logic of the monument' as a sited object that communicates symbolically about site-specific ideas (in contrast to the Modernist monument, which reduced the role of context). Positions taken by art practitioners include 'un' and 'anti' monumental, and once these works are analysed, the extent to which these labels can fit art practices not specifically labeled by these names can be evaluated. For example, 'un' monumental can be considered in terms of its aim to provoke contemplation (and therefore daydreaming (Bachelard)), through isolating aspects of the monument (according to Krauss's definition), a strategy that fits with Rachel Whiteread's $4^{\text {th }}$ plinth project, Monument, for example. The monument can be considered in

1 Inside here, my smartphone based artwork, offers a relational experience of altitude regarding a subjectively marked 'home'. 
relation to installation-based works (Hiller and Hirschhorn); when considered with reference to public installation works, this has implications of public ownership versus the individual private subjective experience, and perhaps points to a tension in the, constantly in flux, public realm, between the individual and collective. These extremely important dimensions of lived experience are fundamentally affective and process-based and the importance of lived experience is foregrounded in artworks such as Alys and Ortega's One Minute of Silence (2003), a time-based networked and collaborative piece that decontextualised the experience usually attached to a place. A process-based reading of House and other works supports ideas of the relational dimensions of the monumental marker and its connection to contemplation. The act of exchange (e.g. in correspondence art) can also be considered to be marked in a similar way, because of its relational dimensions. Following on from this, one might consider ways in which new developments in technology facilitate or disturb a progression in art moving away from the urban plaza which is reflected in the trend from one type of collective experience to another (Price). There is a progression from correspondence art of the 1970s through DIWO (1990s and 2000s) to more recent network- and internet-based art, in which media control and power dynamics continue to shift.

\section{Intentions: Conversations, Experiences and Knowledge, Royal College of Art, London, 2017}

I included my ephemeral zine what is public space? in this exhibition (Intentions, 2017, p.10). In my diarist documentarist art practice, I use correspondence art techniques (such as this zine) and moving image works as well as installation and sound in order to explore site as relational and personal. This artwork, although playful, requests a performative response within the exhibition space. The zine is a prompt for a shape-making activity which requires the format of the zine to be to be made anew. A letterpress print on each tissue paper zine requests that the zine's original format to be destroyed in response to the question posed by the title of this work (what is public space?). A further request is that an image of the result be emailed to me for posting on my blog. This zine is one of several projects I am working on which are open for responses and information for these can be found on my blog; these projects also include Inside here, my app-form artwork and participative related online artwork, and Seminar, a collaborative moving image project with Cristina Portugal, using a prompt and links to participants' videos that they have posted publicly on Vimeo. 


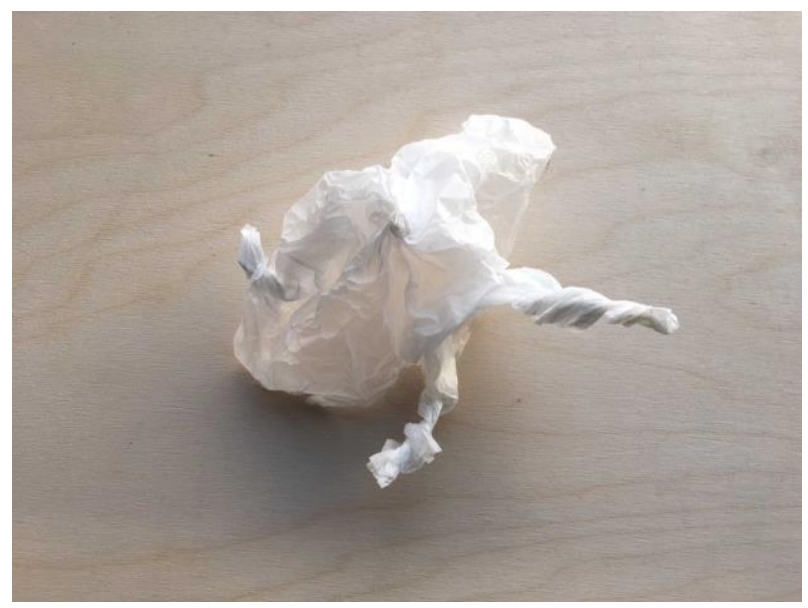

Figure 1: what is public space?, Intentions, 2017

My series of moving image artworks vault, a site analysis of the experiential characteristics of a section of an old pier with a historic connection to a memorial monument in the same town (Knill's monument, St. Ives, Cornwall), treats the affective space of the site as a relic (Tschumi, 1976-1977). In vault I am 're-viewing' the familiar, the everyday, as Hiller has done, however this artwork maps physical sites that can be considered owned public spaces while exploring the ways in which site can be unsettled from its context, a central concern within my art practice (Intentions, 2017, p.10). During the Intentions exhibition vault $(1 \& 2)$ played on a continuous loop and could be viewed on a small retro-style monitor, which has now perhaps become a nostalgic object in its obsolescence (Taussig, 1993). Chairs were made available for viewers, while maintaining the circulation patterns of the surrounding space, creating a privacy gradient (Groys, 2010, p.56) in an effort to allow different types of social contracts of viewing to occur that may correspond to the differing viewing expectations in narrative and non-narrative film. Sitting and watching for a duration is contrasted with non-durational viewing.

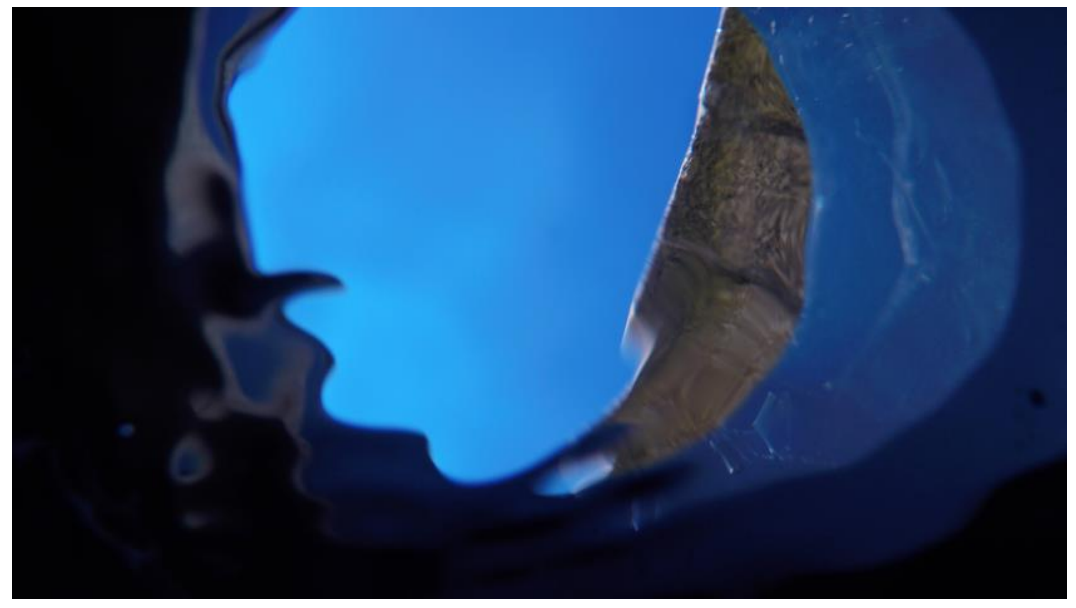

Figure 2: vault 2, Digital film still, Intentions, 2017

Finally, the audio installation Script (Vicky Kim and K M Bosy, 2017) included in Intentions uses correspondence art techniques taking an ongoing collaborative exploration 
within my practice exchange project (Vicky Kim and K M Bosy, 2017-present) as a starting point. Script is explained by text included in the exhibition as staging a "notional discussion around the significance and interpretation of images"; and continues;

"...pairs of voices reflect on the task of searching for images in response to series of specific, yet obscure instructions, before elaborating on the rationale behind their choices. Split between two contact speakers, these conversations are literally divided, hinting at the limits of dialogue, even in the moment of apparent mutual understanding" (Vicky Kim and K M Bosy, Intentions, 2017).

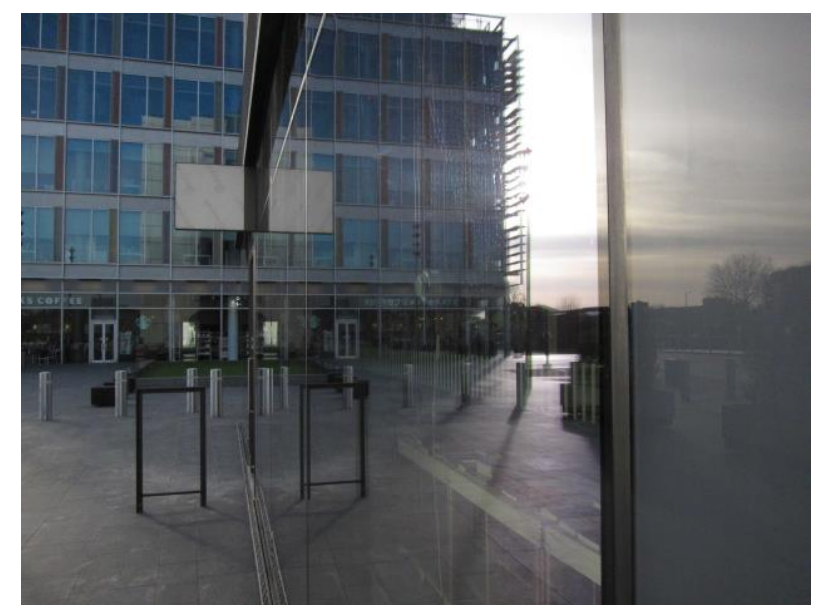

Figure 3: Script, Vicky Kim and K M Bosy, Intentions, 2017

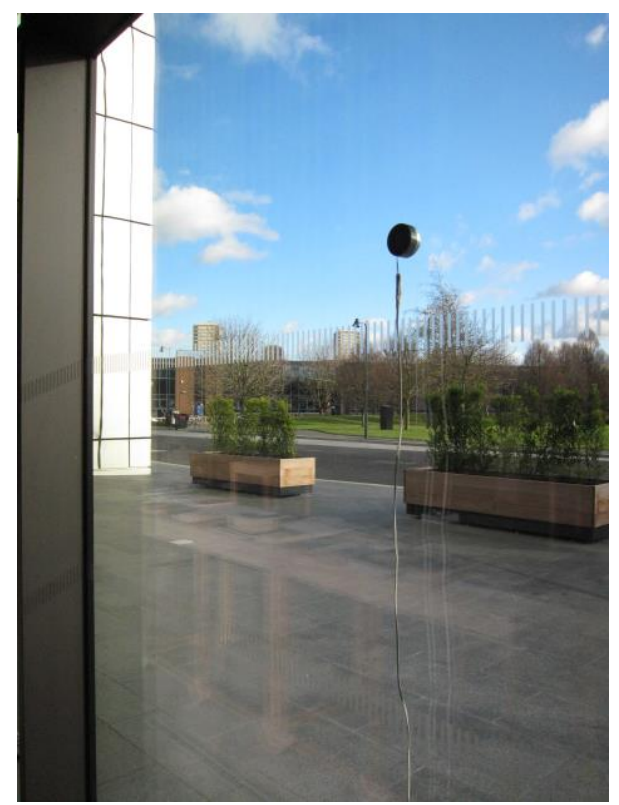

Figure 4: Script, Vicky Kim and K M Bosy, Intentions, 2017 
Intentions: Conversations, Experiences and Knowledge, Royal College of Art, London, 2017.

List of Artworks

what is public space?, 'zine' using letterpress and tissue paper, 2017. (text as follows): What is public space? Please respond by folding, twisting, tearing (for example) this zine. Send me a photo of the result to be used on my blog.

Vault $1 \& 2$, moving image, 2017, on a JVC monitor

Script by Vicky Kim and KMBosy, collaborative sound intervention consisting of surface transducers positioned a distance apart and fixed to window glass, amplifier, iPod, 2017.

\section{References}

Arendt, H. The Human Condition. 2nd ed. University of Chicago Press, Chicago. 1998. (First published: 1958.)

Bachelard, G.; Jolas M.; Gilson E. The Poetics of Space=La Poetiquede l'espace. Beacon Press. Boston. 1994 (first published: Presses Universitaires de France. France. 1957.)

Bishop, Claire. "Black Box, White Cube, Public Space. Published in "Out of Time: Preliminary Materials for Skulptur Projekte 2017.” Biennial Foundation, August 28, 2016. http://www.biennialfoundation.org/2016/08/time-preliminary-materials-skulptur-projekte2017/.

Bosy, K. 2017. "Intentions: Conversations, Experiences and Knowledge." Royal College of Art. https://www.rca.ac.uk/news-and-events/events/intentions-conversations-experiencesand-knowledge/. Accessed March 11, 2018.

Bruno, G. Public Intimacy: Architecture and the Visual Arts. Writing Architecture Series. MIT Press. Cambridge, Mass. 2007.

Doherty, C., ed. Situation. Whitechapel, Documents of Contemporary Art. MIT Press. Cambridge, MA. 2009.

Feldman, B. 2017 "Without Net Neutrality, What Happens to My Netflix?". http://nymag.com/selectall/2017/11/what-happens-to-netflix-when-net-neutrality-isgone.html. (18th March 2018)

Flood, R.; New Museum (New York, N.Y.), eds. Unmonumental: The Object in the 21st Century. Phaidon; New Museum. London, New York. 2007.

Catlow, R.; Garrett m. 2006. "DIWO (Do It With Others)." http://furtherfield.org/projects/diwo-do-it-others-resource. (18th March 2018)

Groys, B. Going Public. E-Flux Journal 3. Sternberg Press. Berlin. 2010.

Gregg, M.; Seigworth G. J. eds. The Affect Theory Reader. Duke University Press, Durham, NC. 2010.

Johnstone, S. ed. The Everyday. Documents of Contemporary Art. MIT Press, Mass. 2008.

Krauss, R. "Sculpture in the Expanded Field." October 8 (1979): 31-44. https://doi.org/10.2307/778224. Accessed March 18, 2018 
Kristeva, J. "The Melancholic Imaginary." New Formations, no. 3: Travelling Theories (Winter 1987).

Lefebvre, H. The Urban Revolution. U of Minnesota Press. 2003.

Massey, D.B. For Space. SAGE, London; Thousand Oaks, Calif. 2005.

Massey, D. B. Space, Place and Gender. Repr. Polity Press, Cambridge. 2007.

Mullins, C. Rachel Whiteread. Tate Gallery Publishing Ltd, London. 2017.

Poster, M. The Mode of Information: Poststructuralism and Social Context. Reprinted. Polity Press, Cambridge. 2004.

Price, S. "Dispersion." NET ART ANTHOLOGY: Dispersion, October 27, 2016. https://anthology.rhizome.org/dispersion. (First published in 1998.) (Accessed February 14, 2018

Rancière, J.; Corcoran, S. Dissensus: On Politics and Aesthetics. Continuum, London; New York. 2010. http://site.ebrary.com/id/10427317. Accessed March 18, 2018

Rosler, M.; Squibb, S. Culture Class. E-Flux Journal 7. Sternberg Press, Berlin. 2013.

Rugg, J. Exploring Site-Specific Art: Issues of Space and Internationalism. London: I. B. Tauris, 2010.

Saper, C. J. Networked Art. University of Minnesota Press, Minneapolis. 2001.

Snow, M. "Wavelength." http://canyoncinema.com/catalog/film/?i=2142snow. Accessed June 7, 2017.

Snow, M. "One Second in Montreal." http://canyoncinema.com/catalog/film/?i=2136. Accessed June 7, 2017.

Szoke, D. "Donna Szoke» Invisible Histories." http://donnaszoke.com/?projects=invisiblehistories. Accessed December 16, 2016.

Taussig, M. T. Mimesis and Alterity: A Particular History of the Senses. Routledge, New York. 1993.

Tschumi, B. "Advertisements for Architecture 1976-1977.". http://www.tschumi.com/projects/19/. Accessed February 14, 2018

Velden, D. van der.; Kruk V.; Kushinski A. 2013 "Captives of the Cloud, Part III: All Tomorrow's Clouds - Journal \#50 December 2013 - e-Flux." 2016. http://www.eflux.com/journal/50/59988/captives-of-the-cloud-part-iii-all-tomorrow-s-clouds/. Accessed March 18, 2018

\section{About the author}

Exhibitions include Another Land exhibition and events programme, at Kingston Museum and Stanley Picker Gallery. 2019, Intentions: Conversations, Experiences and Knowledge exhibition at RCA, London, and $31^{\circ} \mathrm{C}$, ASC Gallery, London, 2017; Thinking through Sound, sound intervention for The Design Museum's opening weekend, November 2016; and Of Improvisation, a pop-up exhibition at Apiary Studios, which launched Inside here, an artwork using a smartphone native app as medium, 2019 update now available, and with a corresponding and on-going online artwork which can be viewed on my blog.

I am based in London, UK, where I am a PhD candidate at the Royal College of Art. Previous to this, I studied painting at OCA(DU) in Toronto and for a postgraduate year at Piazza Independenza Studio, OCA(DU), Florence, Italy. For my graduate education, I studied with Stanley Jones at the Slade School, UCL, University of London, England. 
My work is currently held at The Eagle Gallery (Emma Hill Fine Arts) in London. My workshops What is Public Space? held during Another Land at Kingston Museum and at Waterman's Art Centre, during Trajectories II, London, 2019, will result in a collective|dispersed artwork which will also be found at kmbosy.com/blog.

karen.bosy@network.rca.ac.uk 